\title{
KAJIAN SIMULASI ESTIMASI PARAMETER MODEL GSTAR-GLS UNTUK DATA
} BERPOLA MUSIMAN

Oleh

\author{
Mike Prastuti ${ }^{1)}$ \& Iis Dewi ratih ${ }^{2)}$
}

${ }^{1.2}$ Departemen Statistika Bisnis, Institut Teknologi Sepuluh Nopember, Surabaya

Email : ${ }^{1}$ mike_p@statistika.its.ac.id ${ }^{2}$ iisdewiratih@gmail.com

\begin{abstract}
Abstrak
Secara umum, metode untuk mengestimasi parameter dalam model GSTAR adalah Ordinary Least Squares (OLS). Estimasi parameter dengan menggunakan OLS untuk model GSTAR dengan residual yang berkorelasi akan menghasilkan estimator yang tidak efisien. Metode yang sesuai untuk mengestimasi parameter dengan residual yang berkorelasi adalah Generalized Least Square (GLS). Tujuan dari makalah ini adalah untuk mengusulkan metode GLS untuk mengestimasi parameter dalam model GSTAR Musiman, yang dikenal sebagai GSTAR-GLS, dan membandingkan hasilnya dengan metode OLS atau GSTAR-OLS. Selain itu, tujuan dari makalah ini adalah untuk mengekaji lebih lanjut dalam penentuan bobot spasial yang sesuai pada model GSTAR. Hasil studi simulasi menunjukkan bahwa penentuan bobot spasial pada model GSTAR dapat dilakukan secara optimal dengan menggunakan normalisasi hasil inferensi statistik terhadap parsial korelasi silang antar lokasi pada lag waktu yang bersesuaian. Selain itu, GSTAR-GLS menghasilkan estimator yang lebih efisien daripada GSTAR-OLS, dimana standard error yang dihasilkan lebih kecil.
\end{abstract}

Kata Kunci: GSTAR, GLS, bobot, estimator, dan efisien

\section{PENDAHUALUAN}

GSTAR merupakan suatu model Space-

Time dengan parameter yang tidak harus bernilai sama untuk dependensi waktu maupun dependensi lokasi. Sampai saat ini, sebagian besar penelitian yang berkaitan dengan model GSTAR terbatas pada data spatio-temporal yang stasioner dan non-musimam. Selain itu, kajian estimasi parameter pada penelitian-penelitian model GSTAR yang sudah ada masih terbatas pada estimasi menggunakan metode ordinary least square atau OLS [1], yang selanjutnya ditulis sebagai GSTAR-OLS. Estimasi parameter menggunakan OLS pada model GSTAR dengan residual saling berkorelasi antar persamaan akan menghasilkan estimator yang tidak efisien. Salah satu metode yang sesuai untuk mengestimasi parameter dengan residual saling berkorelasi antar persamaan adalah Generalized Least Square (GLS), yang biasanya digunakan dalam model Seemingly Unrelated Regression (SUR) [2], [3], dan [4]. Metode bobot yang digunakan dalam penelitian ini merupakan pengembangan dari metode bobot normalisasi inferensia statistik terhadap korelasi silang pada lag waktu yang bersesuaian yang diperkenalkan pertama kali oleh [5].

Dalam makalah ini dilakukan kajian simulasi menggunakan data musiman untuk mengkaji metode GLS dalam mengestimasi parameter model GSTAR musiman yang disebut sebagai GSTAR-GLS, dan membandingkan hasilnya dengan metode OLS atau disebut GSTAR-OLS. Selain itu, makalah ini bertujuan untuk mengkaji lebih lanjut tentang penentuan bobot lokasi yang optimal pada model GSTAR dengan menerapkan normalisasi hasil inferensia statistik terhadap parsial korelasi silang antar lokasi pada lag yang bersesuaian dengan orde waktu.

\section{LANDASAN TEORI}

\section{GSTAR (Generalized Space Time Autoregressive) \\ Jika diketahui $\quad\{Z(t): t=0, \pm 1, \pm 2, \cdots \pm T\}$} merupakan sebuah deret waktu multivariat dari $N$ komponen, maka model GSTAR dari orde waktu dan orde spasial $\lambda_{1}, \lambda_{2}, \ldots, \lambda_{p}$, GSTAR (p; $\lambda_{1}$, $\left.\lambda_{2}, \ldots, \lambda_{p}\right)$ dalam notasi matriks dapat ditulis

Vol.13 No.12 Juli 2019 
sebagai berikut (Borovkova, Lopuhaa, \& Ruchjana, 2008),

$$
\mathbf{Z}(\mathrm{t})=\sum_{k=1}^{p}\left[\boldsymbol{\Phi}_{k 0} \mathbf{Z}(t-k)+\sum_{l=1}^{\lambda_{p}} \boldsymbol{\Phi}_{k l} \mathbf{W}^{(l)} \mathbf{Z}(t-k)\right]+\mathbf{e}(t)
$$

dengan :

$\boldsymbol{\Phi}_{k 0}=\operatorname{diag}\left(\phi_{k 0}^{(1)}, \ldots, \phi_{k 0}^{(N)}\right)$ merupakan matrik parameter waktu

$\boldsymbol{\Phi}_{k l}=\operatorname{diag}\left(\phi_{k l}^{(1)}, \ldots, \phi_{k l}^{(N)}\right)$ merupakan parameter spasial

Apabila data yang digunakan mengandung pola musiman, maka model GSTAR yang digunakan adalah model GSTAR musiman. Secara matematis, model GSTAR (p; $\left.\lambda_{1}, \lambda_{2}, \ldots, \lambda_{p}\right)^{s}$ untuk pola data musiman dalam notasi matriks dapat ditulis sebagai berikut:

$$
\mathbf{Z}(\mathrm{t})=\sum_{k=1}^{p}\left[\boldsymbol{\Phi}^{s}{ }_{k 0} \mathbf{Z}(t-s)+\sum_{l=1}^{\lambda_{p}} \boldsymbol{\Phi}_{k l}^{s} \mathbf{W}^{(l)} \mathbf{Z}(t-s)\right]+\mathbf{e}(t)(2)
$$

dengan :

$\boldsymbol{\Phi}_{k 0}^{s}=\operatorname{diag}\left(\phi_{k 0}^{(1)}, \ldots, \phi_{k 0}^{(N)}\right)$ merupakan matrik parameter waktu periode musiman $s$

$\boldsymbol{\Phi}_{k l}^{s}=\operatorname{diag}\left(\phi_{k l}^{(1)}, \ldots, \phi_{k l}^{(N)}\right)$ merupakan parameter spasial periode musiman $s$

Metode yang digunakan sebagai pembobot lokasi dalam GSTAR adalah sebagai berikut,

1. Bobot lokasi seragam

Bobot lokasi ini memberikan nilai bobot yang sama untuk setiap lokasi. Penetuan nilai bobot dalam metode ini adalah :

$$
w_{i j}=\frac{1}{n_{i}}
$$

2. Bobot lokasi invers jarak

Metode ini menggunakan jarak sebenarnya antar lokasi di lapangan. Perhitungan bobot invers jarak diperoleh dari hasil invers jarak sebenarnya kemudian dinormalisasi.

3. Bobot normalisasi inferensia parsial korelasi silang

Metode ini menggunakan normalisasi dari hasil inferensia stastitik terhadap parsial korelasi silang antar lokasi pada lag waktu yang bersesuaian.

\section{SUR (Seemingly Unrelated Regression)}

SUR adalah sistem persamaan yang terdiri dari beberapa persamaan regresi di mana residualnya tidak berkorelasi antar pengamatan dalam satu persamaan, tetapi residualnya

\section{Vol.13 No.12 Juli 2019}

berkorelasi antar persamaan. Informasi adanya residual yang berkorelasi antar persamaan dapat digunakan untuk perbaikan penduga parameter model dengan Generalized Least Square (GLS). GLS adalah penduga parameter regresi yang memperhatikan adanya korelasi dari residual antar persamaan, di mana nilai residual diperoleh dari penaksiran Ordinary Least Square (OLS), yang nantinya digunakan dalam perhitungan untuk menduga koefisien regresi pada sistem persamaan SUR.

Secara umum model SUR untuk $N$ buah persamaan dimana masing-masing persamaan terdiri dari $K$ variabel prediktor dapat ditulis seperti pada persamaan (4).

$$
\begin{aligned}
& Y_{1}=\beta_{10}+\beta_{11} X_{1,1}+\beta_{12} X_{1,2}+\ldots+\beta_{1 K} X_{1, K}+e_{1} \\
& Y_{2}=\beta_{20}+\beta_{21} X_{2,1}+\beta_{22} X_{2,2}+\ldots+\beta_{2 K} X_{2, K}+e_{2} \\
& \vdots \\
& Y_{N}=\beta_{N 0}+\beta_{N 1} X_{N, 1}+\beta_{N 2} X_{N, 2}+\ldots+\beta_{N K} X_{N, K}+e_{N}
\end{aligned}
$$

dengan $i=1,2, \ldots, N$

Menurut Srivastava dan Dwivedi, asumsi yang harus dipenuhi pada persamaan model SUR adalah sebagai berikut :

a. $E(\varepsilon)=0$,

b. $E\left(\boldsymbol{\varepsilon} \boldsymbol{\varepsilon}^{\prime}\right)=\boldsymbol{\sigma}_{i j} \mathbf{I}_{T}$

dimana $i, j=1,2, \ldots, N$.

Kriteria Pemilihan Model Terbaik

Model terbaik dipilih berdasarkan pada model terbaik pada data out sample. Pada kriteria data out sample kriteria model terbaiknya adalah model yang memiliki nilai RMSE terkecil.

$$
R M S E=\sqrt{\frac{1}{M} \sum_{l=1}^{M}\left(Z_{T+l}-\hat{Z}_{T}(l)\right)^{2}}
$$

\section{METODE PENELITIAN}

Penelitian ini terdiri dari dua tujuan utama, yaitu kajian simulasi menggunakan data musiman untuk membandingkan hasil estimasi parameter model GSTAR-OLS dan GSTARGLS. Selain itu, dalam simulasi tersebut juga menerapkan bobot lokasi yaitu normalisasi hasil inferensi statistik terhadap parsial korelasi silang pada lag waktu yang bersesuaian untuk menentukan bobot lokasi yang optimal pada model GSTAR. Ada enam kasus yang berkaitan dengan residual tidak saling berkorelasi dan http://ejurnal.binawakya.or.id/index.php/MBI 
residual saling berkorelasi antar persamaan. Untuk skenario residual tidak saling berkorelasi antar semua persamaan terdiri dari dua kasus, yaitu nilai variansnya adalah sama dan juga berbeda antar lokasi. Sedangkan untuk skenario residual saling berkorelasi ada 4 kasus, yaitu residual saling berkorelasi antar semua persamaan dengan nilai varians adalah sama dan juga berbeda antar lokasi, dan residual tidak semua saling berkorelasi antar persamaan (hanya pada beberapa persamaan saja yang berkorelasi) dengan nilai varians adalah sama dan juga berbeda antar lokasi. Data yang dibangkitkan dalam simulasi ini terdiri dari tiga lokasi dengan $n=300$.

Dalam hal ini, model GSTAR ([12] $]_{1}$ ) yang dibangkitkan secara umum dapat ditulis dalam bentuk sebagai berikut :

$$
\mathbf{Z}_{t}=\left(\boldsymbol{\Phi}_{0}^{12}+\boldsymbol{\Phi}_{1}^{12} \mathbf{W}\right) \mathbf{Z}_{t-12}+\mathbf{e}_{t}
$$

jika diuraikan dalam bentuk matriks adalah sebagai berikut,

$$
\left[\begin{array}{l}
Z_{1, t} \\
Z_{2, t} \\
Z_{3, t}
\end{array}\right]=\left(\left[\begin{array}{ccc}
\phi_{10}^{12} & 0 & 0 \\
0 & \phi_{20}^{12} & 0 \\
0 & 0 & \phi_{30}^{12}
\end{array}\right]+\left[\begin{array}{ccc}
\phi_{11}^{12} & 0 & 0 \\
0 & \phi_{12}^{12} & 0 \\
0 & 0 & \phi_{31}^{12}
\end{array}\right]\left[\begin{array}{ccc}
0 & w_{12} & w_{13} \\
w_{21} & 0 & w_{23} \\
w_{31} & w_{32} & 0
\end{array}\right]\right)\left[\begin{array}{l}
Z_{1, t-12} \\
Z_{2, t-12} \\
Z_{3, t-12}
\end{array}\right]+\left[\begin{array}{l}
e_{1, t} \\
e_{2, t} \\
e_{3, t}
\end{array}\right]
$$

Berdasarkan model pada persamaan diatas, maka persamaan model GSTAR ([12] $\left.]_{1}\right)$ nantinya dapat ditulis dalam bentuk persamaan (8),

$$
\left[\begin{array}{l}
Z_{1, t} \\
Z_{2, t} \\
Z_{3, t}
\end{array}\right]=\left[\begin{array}{lll}
\phi_{11}^{12} & \phi_{12}^{12} & \phi_{13}^{12} \\
\phi_{21}^{12} & \phi_{22}^{12} & \phi_{23}^{12} \\
\phi_{31}^{12} & \phi_{32}^{12} & \phi_{33}^{12}
\end{array}\right]\left[\begin{array}{l}
Z_{1, t-12} \\
Z_{2, t-12} \\
Z_{3, t-12}
\end{array}\right]+\left[\begin{array}{l}
e_{1, t} \\
e_{2, t} \\
e_{3, t}
\end{array}\right]
$$

dengan : $\phi_{i i}=\phi_{i 0}^{12}$, untuk $i=1,2,3$;

$$
\phi_{i j}=w_{i j} \phi_{i 1}^{12} \text { untuk } i, j=1,2,3 \text { dimana } i \neq j
$$

Besar koefisien yang digunakan dalam simulasi ini adalah sebagai berikut,

$$
\left[\begin{array}{l}
Z_{1, t} \\
Z_{2, t} \\
Z_{3, t}
\end{array}\right]=\left[\begin{array}{lll}
0,35 & 0,30 & 0,30 \\
0,25 & 0,45 & 0,25 \\
0,20 & 0,20 & 0,20
\end{array}\right]\left[\begin{array}{l}
Z_{1, t-12} \\
Z_{2, t-12} \\
Z_{3, t-12}
\end{array}\right]+\left[\begin{array}{l}
e_{1, t} \\
e_{2, t} \\
e_{3, t}
\end{array}\right]
$$

\section{HASIL DAN PEMBAHASAN}

Pada bagian ini akan diberikan hasil kajian simulasi berkaitan dengan penerapan metode bobot normalisasi hasil inferensia statistik http://ejurnal.binawakya.or.id/index.php/MBI terhadap parsial korelasi silang pada lag yang bersesuaian dengan orde waktu. selain itu, juga akan dibahas hasil simulasi metode estimasi GLS dan OLS dalam mengestimasi parameter model GSTAR.

\section{Kasus 1.}

Pada bagian ini akan diberikan suatu contoh kasus dimana residual dari data tidak saling berkorelasi antar persamaan atau lokasi pengamatan. Nilai mean yang digunakan adalah nol dan nilai varians adalah sama antar lokasi. Hasil normalisasi inferensia parsial korelasi silang antar lokasi pada lag waktu ke-12 dapat dilihat pada Tabel 1. Hasil Normalisasi inferensia statistik pada Tabel 1 menunjukkan bahwa parsial korelasi silang antar lokasi adalah valid dan sama (sebanding). Artinya, besarnya parsial korelasi silang antara lokasi ke-2 dan ke-3 terhadap lokasi ke-1 adalah sama besar pada lag waktu ke-12. Begitu pula untuk parsial korelasi silang antar

\begin{tabular}{|c|c|c|c|c|}
\hline $\begin{array}{l}\text { Paramete } \\
\mathbf{r}\end{array}$ & $\begin{array}{l}\text { Nilai } \\
\text { Taksira } \\
\quad \text { n }\end{array}$ & $\begin{array}{c}95 \% \\
\text { Batas } \\
\text { Bawa } \\
\text { h } \\
\end{array}$ & $\begin{array}{c}95 \% \\
\text { Bata } \\
\text { S } \\
\text { Atas } \\
\end{array}$ & $\begin{array}{c}\text { Keteranga } \\
\mathbf{n}\end{array}$ \\
\hline$r_{12}(12)$ & 0,291 & 0,178 & 0,404 & \multirow{2}{*}{$\begin{array}{l}\text { Valid dan } \\
\text { sebanding }\end{array}$} \\
\hline $\mathrm{r}_{13}(12)$ & 0,268 & 0,154 & 0,381 & \\
\hline $\mathrm{r}_{21}(12)$ & 0,212 & 0,099 & 0,325 & \multirow{2}{*}{$\begin{array}{l}\text { Valid dan } \\
\text { sebanding }\end{array}$} \\
\hline$r_{23}(12)$ & 0,241 & 0,128 & 0,354 & \\
\hline $\mathrm{r}_{31}(12)$ & 0,287 & 0,173 & 0,400 & \multirow{2}{*}{$\begin{array}{l}\text { Valid dan } \\
\text { sebanding }\end{array}$} \\
\hline$r_{32}(12)$ & 0,245 & 0,132 & 0,358 & \\
\hline
\end{tabular}
lokasi yang lain.

Tabel 1 Taksiran Normalisasi Inferensia Parsial Korelasi Silang antar Lokasi dan Taksiran Interval $95 \%$ pada lag ke-12

Oleh karena itu, metode bobot yang sesuai untuk kasus ini adalah bobot seragam, seperti pada persamaan (10).

$$
\mathbf{W}_{i j}=\left[\begin{array}{lll}
0,0 & 0,5 & 0,5 \\
0,5 & 0,0 & 0,5 \\
0,5 & 0,5 & 0,0
\end{array}\right]
$$

Berdasarkan analisis ini, dapat menjelaskan bahwa bobot lokasi yang diperoleh adalah valid karena bobot lokasi hasil normalisasi inferensia parsial korelasi silang adalah sama

Vol.13 No.12 Juli 2019

\section{Open Journal Systems}


dengan bobot yang digunakan sebelumnya. Dengan menggunakan bobot lokasi ini, diperoleh hasil estimasi parameter model GSTAR([12] $\left.{ }_{1}\right)$ seperti pada Tabel 2.

Tabel 2 Hasil Estimasi Parameter Model GSTAR-OLS dan GSTAR-GLS pada Kasus 1

\begin{tabular}{|c|c|c|c|c|}
\hline \multirow{2}{*}{$\begin{array}{c}\text { Paramete } \\
\mathbf{r}\end{array}$} & \multicolumn{2}{|c|}{ GSTAR-OLS } & \multicolumn{2}{c|}{ GSTAR-GLS } \\
\cline { 2 - 5 } & $\begin{array}{c}\text { Nilai } \\
\text { Koefisien }\end{array}$ & $\begin{array}{c}\text { Standard } \\
\text { Error }\end{array}$ & $\begin{array}{c}\text { Nilai } \\
\text { Koefisien }\end{array}$ & $\begin{array}{c}\text { Standard } \\
\text { Error }\end{array}$ \\
\hline$\phi_{10}^{12}$ & 0,245 & 0,0506 & 0,244 & 0,0506 \\
\hline$\phi_{11}^{12}$ & 0,582 & 0,0571 & 0,583 & 0,0571 \\
\hline$\phi_{20}^{12}$ & 0,450 & 0,0484 & 0,450 & 0,0484 \\
\hline$\phi_{21}^{12}$ & 0,478 & 0,0621 & 0,478 & 0,0621 \\
\hline$\phi_{30}^{12}$ & 0,269 & 0,0523 & 0,269 & 0,0523 \\
\hline$\phi_{31}^{12}$ & 0,551 & 0,0578 & 0,551 & 0,0578 \\
\hline
\end{tabular}

Hasil estimasi parameter dari kedua model menunjukkan bahwa inferensia statistik pada parameter antar lokasi menghasilkan koefisien untuk semua parameter adalah valid atau tidak sama dengan nol. Koefisien parameter yang dihasilkan oleh kedua model adalah relatif sama, baik besar ataupun tanda dari koefisien dengan model pada persamaan (9). Selain itu, Tabel 2 juga menunjukkan bahwa model GSTAR-OLS dan GSTAR-GLS menghasilkan nilai taksiran parameter dengan standard error yang sama antara keduanya.

\section{Kasus 2.}

Skenario pada studi kasus kedua, adalah residual tidak saling berkorelasi antar semua persamaan, namun nilai varians yang digunakan adalah berbeda antar lokasi. Hasil normalisasi inferensia parsial korelasi silang antar lokasi pada lag waktu ke-12 dapat dilihat pada Tabel 3.

Tabel 3 Taksiran Normalisasi Inferensia Parsial Korelasi Silang antar Lokasi dan Taksiran Interval $95 \%$ pada Lag ke-12

\begin{tabular}{|c|c|c|c|c|}
\hline Parameter & $\begin{array}{c}\text { Nilai } \\
\text { Taksiran }\end{array}$ & $\begin{array}{c}\text { 95\% } \\
\text { Batas } \\
\text { Bawah } \\
\end{array}$ & $\begin{array}{c}95 \% \\
\text { Batas } \\
\text { Atas } \\
\end{array}$ & Keterangan \\
\hline $\mathrm{r}_{12}(12)$ & 0,287 & 0,174 & 0,400 & \multirow{2}{*}{$\begin{array}{l}\text { Valid dan } \\
\text { sebanding }\end{array}$} \\
\hline$r_{13}(12)$ & 0,281 & 0,168 & 0,394 & \\
\hline $\mathbf{r}_{21}(12)$ & 0,273 & 0,160 & 0,386 & \multirow{2}{*}{$\begin{array}{l}\text { Valid dan } \\
\text { sebanding }\end{array}$} \\
\hline$r_{23}(12)$ & 0,169 & 0,056 & 0,282 & \\
\hline
\end{tabular}

Vol.13 No.12 Juli 2019

\begin{tabular}{|l|l|l|l|l|}
\hline$r_{31}(12)$ & 0,215 & 0,102 & 0,328 & \multirow{2}{*}{$\begin{array}{l}\text { Valid dan } \\
\text { sebanding }\end{array}$} \\
\hline$r_{32}(12)$ & 0,200 & 0,087 & 0,314 & \\
\hline
\end{tabular}

Hasil Normalisasi inferensia stastistik pada Tabel 3 menunjukkan bahwa parsial korelasi silang antar lokasi adalah valid dan sama (sebanding). Oleh karena itu, metode bobot yang sesuai untuk kasus ini adalah bobot seragam seperti pada persamaan (10). Berdasarkan analisis ini, dapat menjelaskan bahwa bobot lokasi yang diperoleh adalah valid. Dengan menggunakan bobot lokasi ini, diperoleh hasil estimasi parameter model GSTAR([12] $\left.]_{1}\right)$ seperti pada Tabel 4.

Tabel 4 Hasil Estimasi Parameter Model GSTAR-OLS dan GSTAR-GLS pada Kasus 2

\begin{tabular}{|c|c|c|c|c|}
\hline \multirow{2}{*}{$\begin{array}{c}\text { Paramete } \\
\mathbf{r}\end{array}$} & \multicolumn{2}{|c|}{ GSTAR-OLS } & \multicolumn{2}{c|}{ GSTAR-GLS } \\
\cline { 2 - 5 } Koefisien & $\begin{array}{c}\text { Standard } \\
\text { Error }\end{array}$ & $\begin{array}{c}\text { Nilai } \\
\text { Koefisien }\end{array}$ & $\begin{array}{c}\text { Standard } \\
\text { Error }\end{array}$ \\
\hline$\phi_{10}^{12}$ & 0,389 & 0,0495 & 0,389 & 0,0495 \\
\hline$\phi_{11}^{12}$ & 0,571 & 0,0651 & 0,571 & 0,0651 \\
\hline$\phi_{20}^{12}$ & 0,402 & 0,0514 & 0,401 & 0,0514 \\
\hline$\phi_{21}^{12}$ & 0,483 & 0,0625 & 0,483 & 0,0625 \\
\hline$\phi_{30}^{12}$ & 0,368 & 0,0525 & 0,368 & 0,0525 \\
\hline$\phi_{31}^{12}$ & 0,398 & 0,0509 & 0,397 & 0,0509 \\
\hline
\end{tabular}

Hasil estimasi parameter dari kedua model menunjukkan bahwa inferensia statistik pada parameter antar lokasi menghasilkan koefisien untuk semua parameter adalah valid atau tidak sama dengan nol. Tabel 4 juga menunjukkan bahwa model GSTAR-OLS dan GSTAR-GLS menghasilkan nilai taksiran parameter dengan standard error yang sama antara keduanya.

Kasus 3.

Pada kasus ketiga, residualnya adalah saling berkorelasi antar semua persamaan atau lokasi, dengan mean nol dan nilai varians adalah sama antar lokasi. Hasil normalisasi inferensia parsial korelasi silang antar lokasi pada lag waktu ke-12 dapat dilihat pada Tabel 5. Tabel 5 menunjukkan bahwa hasil normalisasi inferensia parsial korelasi silang antar lokasi adalah valid 
dan sama (sebanding). Oleh karena itu, metode bobot yang sesuai untuk kasus ini adalah bobot seragam seperti pada persamaan (10). Sehingga metode bobot yang digunakan adalah valid. Dengan menggunakan bobot lokasi ini, diperoleh hasil estimasi parameter model GSTAR ([12] $\left.]_{1}\right)$ seperti pada Tabel 6 .

Tabel 5 Taksiran Normalisasi Inferensia Parsial

Korelasi Silang antar Lokasi dan Taksiran

Interval $95 \%$ pada Lag ke-12

\begin{tabular}{|c|c|c|c|c|}
\hline Parameter & $\begin{array}{c}\text { Nilai } \\
\text { Taksiran }\end{array}$ & $\begin{array}{c}95 \% \\
\text { Batas } \\
\text { Bawah }\end{array}$ & $\begin{array}{l}95 \% \\
\text { Batas } \\
\text { Atas } \\
\end{array}$ & Keterangan \\
\hline $\mathrm{r}_{12}(12)$ & 0,258 & 0,145 & 0,371 & \multirow{2}{*}{$\begin{array}{l}\text { Valid dan } \\
\text { sebanding }\end{array}$} \\
\hline $\mathrm{r}_{13}(12)$ & 0,323 & 0,209 & 0,436 & \\
\hline$r_{21}(12)$ & 0,331 & 0,218 & 0,444 & \multirow{2}{*}{$\begin{array}{l}\text { Valid dan } \\
\text { sebanding }\end{array}$} \\
\hline$r_{23}(12)$ & 0,255 & 0,142 & 0,368 & \\
\hline $\mathrm{r}_{31}(12)$ & 0,255 & 0,141 & 0,368 & \multirow{2}{*}{$\begin{array}{l}\text { Valid dan } \\
\text { sebanding }\end{array}$} \\
\hline$r_{32}(12)$ & 0,273 & 0,160 & 0,386 & \\
\hline
\end{tabular}

Hasil estimasi parameter dari kedua model menunjukkan bahwa inferensia statistik pada parameter antar lokasi menghasilkan koefisien untuk semua parameter adalah valid atau tidak sama dengan nol. Tabel 6 juga menunjukkan bahwa model GSTAR-GLS menghasilkan nilai standard error yang lebih kecil daripada GSTAR-OLS. Hal ini menunjukkan bahwa model GSTAR-GLS akan menghasilkan nilai taksiran parameter yang lebih efisien daripada model GSTAR-OLS.

Tabel 6 Hasil Estimasi Parameter Model GSTAR-OLS dan GSTAR-GLS pada Kasus 3

\begin{tabular}{|c|c|c|c|c|c|}
\hline \multirow{2}{*}{$\begin{array}{l}\text { Para } \\
\text { meter }\end{array}$} & \multicolumn{2}{|c|}{ GSTAR-OLS } & \multicolumn{2}{|c|}{ GSTAR-GLS } & \multirow[b]{2}{*}{$\begin{array}{c}\text { Efisi } \\
\text { ensi }\end{array}$} \\
\hline & $\begin{array}{c}\text { Nilai } \\
\text { Koefisien }\end{array}$ & $\begin{array}{c}\text { Standard } \\
\text { Error }\end{array}$ & $\begin{array}{c}\text { Nilai } \\
\text { Koefisien }\end{array}$ & $\begin{array}{c}\text { Standard } \\
\text { Error }\end{array}$ & \\
\hline$\phi_{10}^{12}$ & 0,302 & 0,0695 & 0,303 & 0,0568 & $18,8 \%$ \\
\hline$\phi_{11}^{12}$ & 0,653 & 0,0810 & 0,651 & 0,0672 & $17,3 \%$ \\
\hline$\phi_{20}^{12}$ & 0,276 & 0,0673 & 0,327 & 0,0551 & $17,9 \%$ \\
\hline$\phi_{21}^{12}$ & 0,660 & 0,0742 & 0,606 & 0,0617 & $17,6 \%$ \\
\hline$\phi_{30}^{12}$ & 0,345 & 0,0609 & 0,321 & 0,0568 & $6,7 \%$ \\
\hline$\phi_{31}^{12}$ & 0,448 & 0,0540 & 0,468 & 0,0510 & $5,6 \%$ \\
\hline
\end{tabular}

Kasus 4.

http://ejurnal.binawakya.or.id/index.php/MBI

Open Journal Systems
Studi kasus keempat adalah sama dengan kasus ketiga, yaitu residual saling berkorelasi antar semua persamaan. Namun, nilai varians yang digunakan antar lokasi adalah berbeda. Hasil normalisasi inferensia parsial korelasi silang antar lokasi pada lag waktu ke-12 dapat dilihat pada Tabel 7.

Tabel 7 Taksiran Normalisasi Inferensia Parsial Korelasi Silang antar Lokasi dan Taksiran Interval $95 \%$ pada Lag ke-12

\begin{tabular}{|c|c|c|c|c|}
\hline Parameter & $\begin{array}{c}\text { Nilai } \\
\text { Taksiran }\end{array}$ & $\begin{array}{c}\text { 95\% } \\
\text { Batas } \\
\text { Bawah }\end{array}$ & $\begin{array}{c}95 \% \\
\text { Batas } \\
\text { Atas }\end{array}$ & Keterangan \\
\hline $\mathrm{r}_{12}(12)$ & 0,307 & 0,193 & 0,420 & \multirow{2}{*}{$\begin{array}{l}\text { Valid dan } \\
\text { sebanding }\end{array}$} \\
\hline$r_{13}(12)$ & 0,144 & 0,031 & 0,257 & \\
\hline $\mathbf{r}_{21}(12)$ & 0,311 & 0,198 & 0,425 & \multirow{2}{*}{$\begin{array}{l}\text { Valid dan } \\
\text { sebanding }\end{array}$} \\
\hline $\mathbf{r}_{23}(12)$ & 0,235 & 0,122 & 0,348 & \\
\hline $\mathrm{r}_{31}(12)$ & 0,165 & 0,052 & 0,278 & \multirow{2}{*}{$\begin{array}{l}\text { Valid dan } \\
\text { sebanding }\end{array}$} \\
\hline $\mathbf{r}_{32}(12)$ & 0,156 & 0,043 & 0,270 & \\
\hline
\end{tabular}

Tabel 7 menunjukkan bahwa hasil normalisasi inferensia parsial korelasi silang antar lokasi adalah valid dan sama (sebanding). Oleh karena itu, metode bobot yang sesuai untuk kasus ini adalah bobot seragam seperti pada persamaan (10). Sehingga metode bobot yang digunakan adalah valid. Dengan menggunakan bobot lokasi ini, diperoleh hasil estimasi parameter model GSTAR([12] $\left.]_{1}\right)$ seperti pada Tabel 8

Hasil estimasi parameter dari kedua model menunjukkan bahwa inferensia statistik pada parameter antar lokasi menghasilkan koefisien untuk semua parameter adalah valid atau tidak sama dengan nol. Hasil estimasi parameter pada Tabel 8 juga menunjukkan bahwa model GSTAR-GLS menghasilkan nilai standard error yang lebih kecil daripada GSTAR-OLS. Hal ini menunjukkan bahwa model GSTAR-GLS akan menghasilkan nilai taksiran parameter yang lebih efisien daripada model GSTAR-OLS. 
Tabel 8 Hasil Estimasi Parameter Model GSTAR-OLS dan GSTAR-GLS pada Kasus 4

\begin{tabular}{|c|c|c|c|c|c|}
\hline \multirow{2}{*}{$\begin{array}{c}\text { Parame } \\
\text { ter }\end{array}$} & \multicolumn{2}{|c|}{ GSTAR-OLS } & \multicolumn{2}{|c|}{ GSTAR-GLS } & \multirow[b]{2}{*}{$\begin{array}{c}\text { Efisien } \\
\quad \text { si }\end{array}$} \\
\hline & $\begin{array}{c}\text { Nilai } \\
\text { Koefisie } \\
\text { n }\end{array}$ & $\begin{array}{l}\text { Standar } \\
\text { d Error }\end{array}$ & $\begin{array}{c}\text { Nilai } \\
\text { Koefisie } \\
n\end{array}$ & $\begin{array}{l}\text { Standar } \\
\text { d Error }\end{array}$ & \\
\hline$\phi_{10}^{12}$ & 0,394 & 0,0691 & 0,379 & 0,0585 & $15,3 \%$ \\
\hline$\phi_{11}^{12}$ & 0,489 & 0,0792 & 0,507 & 0,0680 & $14,1 \%$ \\
\hline$\phi_{20}^{12}$ & 0,417 & 0,0530 & 0,396 & 0,0491 & $7,4 \%$ \\
\hline$\phi_{21}^{12}$ & 0,521 & 0,0623 & 0,544 & 0,0584 & $6,3 \%$ \\
\hline$\phi_{30}^{12}$ & 0,302 & 0,0610 & 0,334 & 0,0552 & $9,5 \%$ \\
\hline$\phi_{31}^{12}$ & 0,402 & 0,0566 & 0,376 & 0,0524 & $7,4 \%$ \\
\hline
\end{tabular}

Kasus 5.

Pada kasus kelima, akan diberikan suatu contoh kasus dimana residualnya saling berkorelasi hanya pada beberapa persamaan saja, dengan mean nol dan nilai varians antar lokasi adalah sama. Hasil normalisasi inferensia parsial korelasi silang antar lokasi pada lag waktu ke-12 dapat dilihat pada Tabel 9.

Tabel 9 Taksiran Normalisasi Inferesia Parsial

Korelasi Silang antar Lokasi dan Taksiran

Interval 95\% pada Lag ke-12

\begin{tabular}{|c|c|c|c|c|}
\hline Parameter & $\begin{array}{c}\text { Nilai } \\
\text { Taksiran }\end{array}$ & $\begin{array}{c}\text { 95\% } \\
\text { Batas } \\
\text { Bawah }\end{array}$ & $\begin{array}{c}95 \% \\
\text { Batas } \\
\text { Atas } \\
\end{array}$ & Keterangan \\
\hline$r_{12}(12)$ & 0,215 & 0,102 & 0,328 & \multirow{2}{*}{$\begin{array}{c}\text { Valid dan } \\
\text { sebanding }\end{array}$} \\
\hline $\mathrm{r}_{13}(12)$ & 0,248 & 0,134 & 0,361 & \\
\hline$r_{21}(12)$ & 0,263 & 0,150 & 0,376 & \multirow{2}{*}{$\begin{array}{l}\text { Valid dan } \\
\text { sebanding }\end{array}$} \\
\hline $\mathbf{r}_{23}(12)$ & 0,297 & 0,184 & 0,410 & \\
\hline $\mathrm{r}_{31}(12)$ & 0,180 & 0,067 & 0,293 & \multirow{2}{*}{$\begin{array}{l}\text { Valid dan } \\
\text { sebanding }\end{array}$} \\
\hline$r_{32}(12)$ & 0,123 & 0,010 & 0,236 & \\
\hline
\end{tabular}

Tabel 9 menunjukkan bahwa hasil normalisasi inferensia parsial korelasi silang antar lokasi adalah valid dan sama (sebanding). Oleh karena itu, metode bobot yang sesuai untuk kasus ini adalah bobot seragam seperti pada persamaan (10). Sehingga metode bobot yang digunakan adalah valid. Dengan menggunakan bobot lokasi ini, diperoleh hasil estimasi parameter model $\operatorname{GSTAR}\left([12]_{1}\right)$ seperti pada Tabel 10.
Hasil estimasi parameter dari kedua model menunjukkan bahwa inferensia statistik pada parameter antar lokasi menghasilkan koefisien untuk semua parameter adalah valid atau tidak sama dengan nol. Tabel 10 juga menunjukkan bahwa model GSTAR-GLS menghasilkan nilai standard error yang lebih kecil daripada GSTAR-OLS. Hal ini menunjukkan bahwa model GSTAR-GLS menghasilkan estimasi parameter yang lebih efisien daripada model GSTAR-OLS.

Tabel 10 Hasil Estimasi Parameter Model GSTAR-

OLS dan GSTAR-GLS pada Kasus 5

\begin{tabular}{|c|c|c|c|c|c|}
\hline \multirow[b]{2}{*}{$\underset{\mathbf{r}}{\text { Paramete }}$} & \multicolumn{2}{|c|}{ GSTAR-OLS } & \multicolumn{2}{|c|}{ GSTAR-GLS } & \multirow{2}{*}{$\begin{array}{l}\text { Efisiens } \\
\quad \text { i }\end{array}$} \\
\hline & $\begin{array}{c}\text { Nilai } \\
\text { Koefisien }\end{array}$ & $\begin{array}{l}\text { Standar } \\
\text { d Error }\end{array}$ & $\begin{array}{c}\text { Nilai } \\
\text { Koefisie } \\
\text { n }\end{array}$ & $\begin{array}{c}\text { Standard } \\
\text { Error }\end{array}$ & \\
\hline$\phi_{10}^{12}$ & 0,392 & 0,0544 & 0,379 & 0,0500 & $7,4 \%$ \\
\hline$\phi_{11}^{12}$ & 0,515 & 0,0627 & 0,528 & 0,0583 & $6,5 \%$ \\
\hline$\phi_{20}^{12}$ & 0,431 & 0,0491 & 0,439 & 0,0473 & $4,1 \%$ \\
\hline$\phi_{21}^{12}$ & 0,535 & 0,0549 & 0,526 & 0,0532 & $1,9 \%$ \\
\hline$\phi_{30}^{12}$ & 0,447 & 0,0689 & 0,417 & 0,0607 & $11,8 \%$ \\
\hline$\phi_{31}^{12}$ & 0,345 & 0,0668 & 0,373 & 0,0600 & $9,1 \%$ \\
\hline
\end{tabular}

Kasus 6.

Pada kasus ini residualnya adalah saling berkorelasi hanya pada beberapa persamaan saja. Namun nilai varians antar lokasi yang digunakan adalah berbeda. Hasil normalisasi inferensia parsial korelasi silang antar lokasi pada lag waktu ke-12 dapat dilihat pada Tabel 11.

Tabel 11 Taksiran Normalisasi Inferensia Parsial Korelasi Silang antar Lokasi dan Taksiran Interval $95 \%$ pada Lag ke-12

\begin{tabular}{|c|c|c|c|c|}
\hline Parameter & $\begin{array}{c}\text { Nilai } \\
\text { Taksiran }\end{array}$ & $\begin{array}{l}95 \% \\
\text { Batas } \\
\text { Bawah }\end{array}$ & $\begin{array}{c}95 \% \\
\text { Batas } \\
\text { Atas }\end{array}$ & Keterangan \\
\hline $\mathrm{r}_{12}(12)$ & 0,363 & 0,250 & 0,476 & \multirow{2}{*}{$\begin{array}{l}\text { Valid dan } \\
\text { sebanding }\end{array}$} \\
\hline $\mathrm{r}_{13}(12)$ & 0,338 & 0,224 & 0,451 & \\
\hline$r_{21}(12)$ & 0,340 & 0,227 & 0,453 & \multirow{2}{*}{$\begin{array}{l}\text { Valid dan } \\
\text { sebanding }\end{array}$} \\
\hline $\mathrm{r}_{23}(12)$ & 0,207 & 0,094 & 0,321 & \\
\hline $\mathrm{r}_{31}(12)$ & 0,124 & 0,010 & 0,237 & \multirow{2}{*}{$\begin{array}{l}\text { Valid dan } \\
\text { sebanding }\end{array}$} \\
\hline$r_{32}(12)$ & 0,182 & 0,069 & 0,295 & \\
\hline
\end{tabular}


Tabel 11 menunjukkan bahwa hasil normalisasi parsial korelasi silang antar lokasi adalah valid dan sama (sebanding). Oleh karena itu, metode bobot yang sesuai untuk kasus ini adalah bobot seragam seperti pada persamaan (10). Sehingga metode bobot yang digunakan adalah valid. Dengan menggunakan bobot lokasi ini, diperoleh hasil estimasi parameter model GSTAR([12] $\left.]_{1}\right)$ seperti pada Tabel 12.

Hasil estimasi parameter dari kedua model menunjukkan bahwa inferensia statistik pada parameter antar lokasi menghasilkan koefisien untuk semua parameter adalah valid atau tidak sama dengan nol. Tabel 12 juga menunjukkan bahwa model GSTAR-GLS menghasilkan nilai standard error yang lebih kecil daripada GSTAR-OLS. Hal ini menunjukkan bahwa model GSTAR-GLS menghasilkan estimasi parameter yang lebih efisien daripada model GSTAR-OLS.

Tabel 12 Hasil Estimasi Parameter Model GSTAROLS dan GSTAR-GLS pada Kasus 6

\begin{tabular}{|c|c|c|c|c|c|}
\hline \multirow[b]{2}{*}{$\begin{array}{l}\text { Paramet } \\
\text { er }\end{array}$} & \multicolumn{2}{|c|}{ GSTAR-OLS } & \multicolumn{2}{|c|}{ GSTAR-GLS } & \multirow[b]{2}{*}{$\begin{array}{c}\text { Efisien } \\
\text { si }\end{array}$} \\
\hline & $\begin{array}{c}\text { Nilai } \\
\text { Koefisie } \\
n \\
\end{array}$ & $\begin{array}{l}\text { Standar } \\
\text { d Error }\end{array}$ & $\begin{array}{c}\text { Nilai } \\
\text { Koefisie } \\
\text { n }\end{array}$ & $\begin{array}{l}\text { Standar } \\
\text { d Error }\end{array}$ & \\
\hline$\phi_{10}^{12}$ & 0,303 & 0,0529 & 0,342 & 0,0461 & $12,9 \%$ \\
\hline$\phi_{11}^{12}$ & 0,702 & 0,0604 & 0,659 & 0,0533 & $11,8 \%$ \\
\hline$\phi_{20}^{12}$ & 0,424 & 0,0533 & 0,384 & 0,0466 & $12,6 \%$ \\
\hline$\phi_{21}^{12}$ & 0,528 & 0,0582 & 0,569 & 0,0516 & $11,3 \%$ \\
\hline$\phi_{30}^{12}$ & 0,356 & 0,0824 & 0,409 & 0,0608 & $26,2 \%$ \\
\hline$\phi_{31}^{12}$ & 0,449 & 0,0732 & 0,403 & 0,0552 & $24,6 \%$ \\
\hline
\end{tabular}

\section{PENUTUP}

\section{Kesimpulan}

Penentuan bobot lokasi pada model GSTAR-OLS dan GSTAR-GLS dapat dilakukan secara optimal melalui normalisasi hasil inferensia statistik terhadap parsial korelasi silang antar lokasi pada lag yang bersesuaian dengan orde waktu. Selain itu, hasil simulasi menunjukkan bahwa jika residual dari data saling berkorelasi antar semua persamaan ataupun hanya beberapa persamaan saja yang saling berkorelasi, maka model GSTAR-GLS akan menghasilkan estimasi parameter yang lebih efisien daripada model GSTAR-OLS. Hal itu dibuktikan dari nilai standard error yang dihasilkan oleh model GSTAR-GLS adalah lebih kecil daripada GSTAR-OLS. Sedangkan jika residual tidak saling berkorelasi antar semua persamaan, maka nilai standard error yang dihasilkan oleh model GSTAR-OLS dan GSTAR-GLS adalah sama.

\section{Saran}

Saran dari penelitian ini adalah metode bobot spasial normalisasi inferensia parsial korelasi silang serta metode GSTAR-GLS sebaiknya dicoba digunakan pada data dengan pola selain musiman misalnya data dimana variabel yang digunakan dipengaruhi oleh variabel lain dari luar (eksogen) baik variabel eksogen dengan skala metrik atau nonmetrik.

\section{DAFTAR PUSTAKA}

[1] Borovkova, S.A., Lopuhaa, H.P., dan Ruchjana, B.N. 2008. Consistency and asymptotic normality of least square estimators in generalized STAR models. Journal Compilation Statistica Neerlandica 62 (4) : 482-508.

[2] Zellner, A. (1962). An efficient method of estimating seemingly unrelated regression equations and tests for aggregation bias. Journal of the American Statistical Association 57 : 348-368.

[3] Srivastava, V.K. dan T.D. Dwivedi. (1979). Estimation of seemingly unrelated regression equations models: a brief Survey, Journal Econometrics, Vol. 10, hal. 15-32.

[4] Henningsen, A., dan Hamann, J. D. (2007). systemfit: A package for estimating systems of simultaneous equations in $\mathrm{R}$. Journal of Statistical Software, Vol. 23, No.4, hal. 1-40.

[5] Suhartono dan Subanar. 2006. The Optimal Determination of Space Weight in GSTAR Model by Using Cross-correlation Inference, Journal of Quantitative Methods. Journal 
Devoted the Mathematical and Statistical

Application in Various Field 2 (2) : 45-53 